\title{
Tedavi Yöntemleri Açısından Selçuklu ve Bizans Pratikleri'nin Tahlili
}

\author{
An Analysis Of The Seljuk And Byzantine Practices Apropos Of \\ Treatment Methods
}

\section{Seyhan Atak *}

Öz

Bizans ve Selçuklu devletlerinde, göçler ve savaşlar neticesinde birçok salgın hastalık yayılmış ve binlerce insanın ölmesine sebep olmuştur. Bu salgın hastalıkların başında; sıtma, veba ve cüzzam gibi hastalıklar gelmektedir. Bu salgınlar sonucunda Bizans ve Selçuklu tıbbı, hastalıkların tedavi edilmesi amacıyla pek çok çalışma yapmışlar ve birçok tedavi yöntemi geliştirmişlerdir. Tedavi yöntemlerinin başında bitkisel, hayvansal unsurları kullanmalarının yanı sıra sihir, tılsım, büyüsel unsurlar ön plandadır. Bu tedavi yöntemi ve uygulamalarında, İslami dönem hekimleri İbn Sînâ, er-Ebû Bekir Râzî ve Bîrûnî'nin uygulama ve yöntemleri hem Bizans hem de Selçuklu devletleri tarafından kaynak olarak alınmıştır. Bununla beraber Bizans'ın uygulama ve yöntemlerinin daha çok Roma İmparatorluğu ekseninde ilerlediği bilinmektedir.

Anahtar Kelimeler: Selçuklu Tedavi, Bizans Tedavi, Veba, Sıtma, Cüzzam

YLS Öğrencisi, Sakarya Üniversitesi Sosyal Bilimler Enstitüsü, Tarih Anabilim Dalı, Ortaçağ Tarihi Bilim Dalı, (seyhan.atak@ogr.sakarya.edu.tr)

$\mathrm{Bu}$ makale iThenticate sistemi tarafından taranmıştır.

Makale Gönderim Tarihi: 3 Nisan 2019 


\begin{abstract}
Numerous contagious diseases spread within the Byzantine and Seljuk Empires as a result of migrations and battles, causing thousands to die. These diseases are primarily exemplified by malaria, plague and leprosy. In response to these diseases, both Byzantine and Seljuk disciplines of medicine have carried out various researches and developed treatment methods. While the treatment methods were lead mainly by herbal and animal sources, among them counted also magic, amulets and other forms of witchcraft. In the application of these treatment methods, both Byzantine and Seljuk Empires have been influenced by the methods put forward by Al-Biruni, Al-Razi and Avicenna. Besides, it is evident that the applications in the Byzantine Empire predominately revolves around the Roman Empire.
\end{abstract}

Keywords: Seljuk Treatment, Byzantine Treatment, Plague, Malaria, Leprosy 


\section{Giriş}

İnsanın ilk var oluşundan itibaren tıp hep var olmuştur. Tarihimizde vuku bulan hastalıkların bir çoğu da tekrar eden bir boyuttadır. Bazı hastalıklar şehirlerde daima var olan hastalıklarken, bazıları da büyük olaylar (savaş, doğal afetler, göç) neticesinde yayılan salgın hastalıklardı. Bu muhtelif hastalıklara uygulanan tedavi yöntemleri de Selçuklu ve Bizans tıbbında farklılıklar arz etmekteydi (Ünver, 1938: 9). Tedavi hizmeti insanların, hayvanların ve bitkilerin hastalanmaları durumunda onları iyileştirmek için çeşitli tıbbi yöntemlerin uygulanması şeklinde olmaktaydı. $\mathrm{Bu}$ tedaviler, Selçuklu ve Bizans tıbbında gerek kimyasal ilaçlar gerekse manevi dua yöntemleri ile yapılırdı (Karaman, 2011: 255). Seçuklu devletlerinin tedavi yöntemlerini incelediğimizde çoğunlukla İslami dönem veya Arap tıp tedavi yöntemleri etkisinde kalınmış. Bu hususta, devletlerin kendilerinden önceki yapılanmaların hem devamı olması hem de bünyesinde bulundurduğu yabancı halkın Selçuklu devletiyle karşılıklı etkileşimi ve alışveriş gibi sonuçlar etkiliydi. Bizans devletinin de tıbbi tedavilerinde Doğu Roma İmparatorluğu'nun ve Antik Çağ yansımalarının izleri görülmektedir. (Köroğlu, 2005a: 241).

İslam tabiplerinden Bîrûnî, İbn Sînâ ve Ebû Bekir er-Râzî'nin tedavi metotları, Selçuklu ve Bizans hekimleri tarafından örnek alınan yöntemler arasında olduğunu söylemek mümkündür. Gerek kullanılan ilaçlar gerekse tedavi şeklileri açısından hem Birûni hem İbn Sînâ'nın yöntemleri çerçevesinde yayılarak devam etmişti (Tekiner, 2006: 68). Bu manada Selçuklu tedavilerinin İslam tıbbı çerçevesinde gelişmesi söz konusudur. Bu durumun Bizans devleti tıbbını da etkisi altına aldığını tedavi yöntem ve esaslarına bakıldığında görmek mümkündür. Selçuklu döneminde kullanılan ilaçları tıp tarihi çalışan kaynaklar, Müfred devalar (basit ilaçlar) ve Mürekkep devalar (bileşik ilaçlar) olarak adlandırmıştır (Tekiner, 2014: 187; Baytop, 1985: 66). Basit ilaçlar kategorisinde genellikle bitkisel olan tek türden kullanılan ilaçlar esas alınmaktaydı. Selçuklu devletlerinde basit ilaç yapımında uygulamış oldukları bazı bitkiler: Ayrık otu, böğürtlen, burçak, haşhaş, hatmi, gül, ıhlamur, kimyon, fesleğen, maydonoz, menekşe, papatya, hindi- 
ba, ısırgan, sedef, sarımsak, sinir otu, susam, ebegümeci, kişniş, hardal, çam sakızı, çörek otu, kantaron, keten tohumu, kına, şap, üzerlik, yonca'dır. (Baytop, 1985: 66). Bileşik ilaçlar: yukarıda saydığımız tek türden bitkilere farklı karışımlar yani hayvansal ve minarel kaynaklar eklenerek elde edilen ilaçlar sayılabilir. Çoğunlukla tek türden elde edilen ilaçların fayda sağlamadığı zamanlarda birleşik ilaçlara ihtiyaç duyulmuştur.

Selçuklu ve Bizans Devletleri dönemleri boyunca bir çok hastalıkla karşı karşıya kalmış ve bu hastalıklardan kurtulmak için pek çok tedaviler geliştirmişlerdir. Bu manada gerek Selçuklu gerekse Bizans devletleri öncelikle dönemlerinde vuku bulan salgin hastalıklara karşı uygulamış oldukları tedaviler öncelik teşkil etmektedir. Selçuklu ve Bizans hekimlerinin bilmediğimiz bir çok hastalığa uygulamış olduğu cerrahi müdahaleleri de bulunuyordu. dağlama, mesane ameliyatı, göz ameliyatı, masaj doğal bitkisel karışımlar, hayvansal ilaçlar genellikle uygulanan yöntemlerdi (Kahraman, 2011: 255; Kay, 2008: 21-22; Aydın, 2006: 159 ).

\section{Selçuklu Devletinde Hastalık ve Tedavi Yöntemleri}

Selçuklu hekimleri, tedavi yöntem ve esaslarına kendinden önceki İslam tıbbının devamı niteliğinde olması uygulamalarının da o dönem çizgisinde olmasını sağlamıştır. Selçuklu hekimlerinin tıbbi uygulamalarında hem teorik hem de pratik yöntemleri tercih etmektedi. Bu manada Selçuklular tedavi aşamasında öncelikle yaptıkları işlem nabzın muayenesini yapıp teşhis ve tedavisini gerçekleştirmekti. Hasta hakkında bilgi almak için bu gerekli bir uygulamadır (Ünver, 2014: 8). Nizâmî-i Arûzî, Çehâr Makâlede adlı eserinde İbn Sînâ'nın tedavi yöntem ve gözlemlerine dair önemli bilgiler verir. Arûzi'ye göre İbn Sînâ ilk etapta hastanın nabzına ve idrarına bakmaktaydı. Akabinde idrarının rengi ve yüzünün görüntüsüne göre hastaya bir teşhis belirlerdi. Rivayete göre İbn Sînâ: "Padişahlardan birinin cariyesi çok hastalanır ve hiçbir hekim derman bulamaz nihayet İbn Sînâ adında bir genc şehre gelmiştir. Padişah tarafindan huzura çağrilır. Hasta olan şahsın yanına götürürler. İbn Sînâ karşısında sararmış solmuş bir genç görür, ilk uygulaması gencin nabzını kontrol ve idrarın tahlil yapmaktı. Akabinde gencin yanında 
bulunanlara sorular sordu gurgan'ın sokak, mahallelerin ismi soruldu söylediler bir yandanda gencin nabzın tutarak hareketleri izlediler. Ardından bütün evleri, köşklerin isimlerini saydılar. Sonra ev ahalisinin isimlerini saydılar. Nabzın en zirve yaptığ ismi duyunca o yerde oturan kişiyi gence getirdiler. Hekimin hastalı̆̆ın derdinin aşk olduğunu anlaması üzerine tedavisini gerçekleştirmesi herkesi şaşırtmıştır" (Semerkandi, 2016: 102). Bu manada hekimlerin tedavi yöntem ve esaslarında nabız ve idrar tahlili öncelik teşkil etmekteydi.

$\mathrm{Bu}$ tür tedaviler hekimlere göre hastalığın ilk belirtilerini öğrenmede faydalı bir uygulamadır. Hekimler hastalıkların derecesine göre ilaçlı tedavi metotları uygularlardı. İlaç tedavisi yaramayan hastalara muhtelif cerrahi işlemler uygulanırdı. (Kaya, 2004: 295). Buradaki amaç hastayı ellerinden gelebildiği kadar sağlı̆̆ına kavuşturmaktı. Selçuklu hekimleri durumu ağır olmayan hastalara öncelikle bitkisel tedaviler denerdi. (Kaya, 2003: 250). Durumu ağır olup cerrahi işlem gereken göz ameliyatı, mesane ameliyatı gibi hastalarında ise ameliyat esnasında acı hissi vermeyen deliceotu, esrar, banotu, ve ademotu suyuna batırılmış sünger kullanarak operasyonlar gerçekleştirilirdi (Ünver, 2014: 4; Atçeken ve Yaşar, 2014: 118). Bunun dışında önemli bir tedavi yönelimi de hacamattı. Selçuklu toplumunda özel olarak bulunan hacamatc1lar, hastanın vücudunu keserek pis kanı alarak tedavi etmesi esas olan uygulamadır. Dönemin alimlerinden Mevlânâ'nın kollarından hacamatcıların kan aldıklarını Ahmet Eflaki, Ariflerin Menkıbeleri adlı eserinde nakletmektedir (Eflaki, 1973:189). Dolayısıyla Selçuklu hekimlerinin veya bu iş için özel yetiştirilen hacamatcılar hastalık tedavisinde önemli bir etkiye sahipti.

Selçuklularda görülen hastalıkların başında sıtma, veba salgınları, cüzzam ve akıl hastalıkları gibi salgın hastalıklar ön plandadır. Sıtma hastalığı, Selçuklu toplumunda yaygın olan hastalıklardandı. Genellikle dışarıdan gelen insanlar vasıtası ile bulaşan bir tür salgındır. Sıtma hastalığının tedavisi için Selçuklu hekimleri pek çok tıbbi uygulamanın yanı sıra sarımsak bitkisinin önemli bir etkiye sahip olduğunu zikrederler. Mevlânâ'nın hastalarına sarımsak taneleri yedirip terletmek sureti ile iyileştirdiğini kaynaklardan öğrenmekteyiz. Bu manada Ahmet Eflaki, Ariflerin Menkıbe- 
leri adlı eserinde, sarımsağın sıtma hastalığı üzerindeki etkisine dair bir olay anlatmıştır. Fahreddîn-i Sivâsî adlı şahıs yüksek ateşli bir sıtmaya hastalığına yakalanmıştır. Bu hastalık hususunda hiçbir hekim çare bulamamıştır. Mevlânâ, hastayı ziyaret ettiği esnada ona sarımsağın özünü ezip hastaya yedirmelerini tavsiye eder. Hekimler bu tedavinin hastayı iyileştireceğini düşünmüyorlardı. Fakat bu tadavi uygulandıktan sonra hasta Allah'ın takdiriyle terleyip iyileşmiştir. Hekimler bu tarz bir tedavinin tıp ile ilgisinin olmadığı, Mevlânâ'nın hikmeti dahilinde gerçekleştiğini naklederken sarımsağın tedavideki etkisinin önemini de vurgular. (Eflaki, 1973: 334). Başka bir rivayete göre sıtmalı bir hastaya Mevlânâ, sarımsak taneleri önerir. Fakat hasta bunu yiyemez. Bunun üzerine üç bademin üzerine ezan, izin, besin gibi cümlerin yazılıp hastanın yemesini tavsiye eder. Hasta 3 günde iyileşmiş (Eflaki, 1973: 293). Sitma hastalığının tedavisinde önemli bir etkiye sahip bitkilerden birisi de kınadır (Taneri, 1978: 80).

Selçuklu devletinde vuku bulan salgın hastalıklardan birisi de vebadır. Kaynakların bahsettiği üzere veba, Taun olarak adland1rılmaktadır (Varlık, 2011: 175). Bu hastalık, kemirici hayvanlar s1nıfına giren pire ve farelerden, insanlara ve hayvanlara bulaşarak yayılan bir tür mikrobik hastalıktır (Arık, 1991: 27). Bu hastalık, Selçuklu devletinde 1. Haçlı seferlerinin baş göstermesiyle birlikte Anadolu'da yayılmıştır. Anadolu'nun muhtelif yerlerinde veba salgınlarının vuku bulduğu, bir çok insanın bu hastalık yüzünden öldüğü ve Selçuklu dahil bütün dünyayı sarstığı kaynaklar tarafından zikredilen önemli bir hadisedir. (Abû'l-Farac, 1987: 425; Mateos,1962: 177-178).

Anadolu topraklarında veba hastalığına "Kara ölet" adının verildiğini ve bu hastalıkdan dolayı binlerce kişinin öldüğüne dair rivayetleri el-Ömerî’ den öğrenmekteyiz. Bu hastalıkta ilk belirti insana ateş basması, mide bulantısı ve kan tükürüğüdür. Bu etkilerle ilerleyen hastalık insanların ölmesin sebep olmaktaydı. İnsanlar, veba hastalığından kurtulamayacaklarını düşündükleri için bir müdahale yapmadıkları gibi herhangi bir ilaç da kullanmadıklar1 zikredilir. El-Ömerî, birçok kişinin ölümüne neden olan veba hastalığından vefat kişilerin kefenlenmeden toplu gömüldüğünü 
nakleder (El-Ömeri, 2014: 414). Bu manada hekimlerin, hastalığın tedavisinde kullandıkları yöntemlere ilişkin veriler kısıtlıdır.

Bulaşıcı hastalıklar, eldeki imkanlar dahilinde tedavi edilmekteydi. Bu hususta muhtelif tedavi yöntemleri kullanılıyordu. Kan alma, idrar muayenesi, bitkisel tedaviler şeklinde sıralanabilir. Veba salgınlarından korunmada tedavinin yanı sıra hastalığın yayılmasını önleyecek tedbirler en önde gelir. Bu amaçla ilk olarak karantina sistemi uygulanmıştır. Diğer bir tedbir ise vebalı ölülerin ağzına kazık tıkayarak mikrobun yayılımını engellemek ya da cesedi gömmek şeklinde yapılan uygulamalardı (Arık, 1991: 45). $\mathrm{Bu}$ hastalık hususunda toplumlarda yayılarak bulaşan salgın hastalıklar hep veba diye nitelendirilmişti. Bu manada Hz Peygamber (s.a.v) bir hadisi şerifinde vebanın bulaşıcı bir hastalık olduğu, onun görüldüğü yerden uzaklaşılması gerektiğini dile getirerek hastalık konusunda uyarır (Kesir, 2017: 2851).

Selçuklu toplumunda görülen bir diğer salgın hastalık da cüzzamdır. Bu hastalıkla ilgili önemli bir bilgiyi Ahmet Efalki, Ariflerin Menkıbelerinde şu şekilde nakleder: "Mevlânâ için hazırlanan hamama, cüzzamlıların girmesi üzerine görevliler onları inciterek çıkarmış. Bu durumu gören mevlana hazretleri onları ikaz etmiş ve cüzzamlılarla birlikte soyunarak suya girdiği rivayet edilir" (Eflaki, 1973: 339). Bu rivayete göre Selçuklu toplumunda cüzzam hastalığının var olması ve tedavisinin hamam dahilinde gerçekleştirildiği anlaşılır. Fakat Mevlânâ'nın cüzzamlılarla aynı havuza girmesi eğer onun hikmeti dahilinde değilse bu durumun müridleri tarafından abartılan bir husus olabileceği düşünülmektedir. Zira cüzzam hastalığı bulaşıcı bir hastalıktır. Hatta cüzzam ve veba hastalığına mukabil Hz. Muhammed (s.a.v) hadisi şerifleri vardır. "bu hastalı̆̆ın bir yerde çıktığın işittiğiniz zaman oraya gitmeyiniz. Hastalı sizin bulunduğunuz yerde vuku bulursa ondan kaçmak için sakın o yerden ayrılmayınız" (Keskin, 2014: 84) bu bağlamda ünlü tıp alimi Ebû Bekir er-Râzî de cüzzamı ve vebayı bulaşıcı bir hastalık olarak sınıflandırmıştır. Hz Peygamber'in bir diğer hadisinde de "Cüzzamlıdan arslandan kaçar gibi kaç" buyurduğu zikredilir (Denizkuşları, 2018: 84). Bu hastalığın bulaşıcılığından Mevlana hazretlerinin habersiz olması düşünülemez. Cüzzam hastalığı te- 
davi edilebilir bir hastalıktır. Cüzzamın yayılmasını önlemek esas meseledir.

Selçuklu devletleri döneminde ünlü bulunan hekimlerinin tıbbi tedavi açısından hastalıklara aradıkları çareler, denedikleri tedavi yöntemleri ve aldıkları tedbirler şöyledir: Bu dönemin ünlü hekimlerden birisi Nizâmî-i Arûzî Semerkandî’dir. Büyük Selçuklu Dönemi Sultanı Sultan Sencer ve Melikşah dönemlerinde Nizâmîi'nin tabiplik yaptığı bilinir. Her ne kadar onun hekimlik esnasında yaptığı tedavilere dair bir bilgimiz olmasa da yazmış olduğu Çehâr Makâle adlı eserinden hekimlerin uyguladı̆̆ı yöntemler öğrenilir. Esere göre Selçuklu tedavisinde müshil adını verdikleri ilaç tedavisi başta gelmekteydi. Bu hususta Arûzî; "Bahtişû adında bir hekime ishal olmuş bir zaat geliyor. Bu zaata Bahtişû her gün elli altmış gün kişiyi tuvalete çıkaracak bir müshil hazırlar ve hastaya içirir. Hasta müshili aldığı gün daha çok tuvalete çıkar, diğer günler azalırmış. Nitekim sağlığına kavuşur." Bahtişû, bu hastalığın asıl beyinde geçmesi gerektiği, oradan atılmadığı sürece şifa bulamayacağımızı nakleder (Semerkandi, 2016: 94). Bu hususta tedavinin yanı sıra psikolojik durumların da tedavide önemli bir yerinin olduğudur. Dönemin hekimlerinden Ekmeleddin Tabîb'in de pek çok hastalığ1 müshil adı verilen ilaç ile tedavi ettiğini biliniyordu. Bir gün Mevlânâ hazretleri hastalanır ve onun tedavisi için Ekmeleddin, on yedi çeşit müshil ve haplar hazırlatıp perhiz önererek tedavisini gerçekleştirmiş (Eflaki, 1973: 187). Ekmeleddin'in diğer bir ilaç çeşidi ise tiryaki (panzehir) adını verdiği bir ilaç tedavisidir. (Eflaki, 1973: 339). İlaç tedavilerinin yanı sıra Selçuklular göz perdesi ameliyatı, mesane ameliyatı gibi cerrahi operasyonlarda gerçekleştirmişlerdir. Selçuklu hekimleri, soğuk ve sıcak suyun hastanın vücudundaki etkiye tepkisini ve pek çok ağrı kesici ilaçları da şok tedavisinde kullanmışlardır (Ünver, 2014: 4).

Hastanın, hastalığını anlamak için kan tahlili veya idrar muayenesi yapıldığına ilişkin Nizâmî-i Arûzî, Hekim İbn Sînâ'nın, bir melonkoli hastasını tedavisi sırasında kan tahlili ve idrar muayenesini yaptıktan sonra onun hiçbir hastalığının olmadığı, hasta zaatın aşk acısı çektiğine dair bir gözlemini nakleder (Semerkandi, 2016: 
102). İdrar tahlilinden hastalığın belirlendiğini kâbûsnâmede de zikredilir. Hasta olan zaatın idrarının bir kaba alındığı eğer rengi açık ise hastalığının temiz olduğu eğer rengi turuncu gibi koyu bir renk ise içerisinde kötü bir hastalığın vuku bulduğuna ilişkin tahliller gerçekleştirilirdi. Hastalığın teşhisinde bir diğer yöntem nabız muayenesi ile ölçme metodudur. Bu yöntem kan, safra, balgam, sevda dörtlemesi adı verilen bir sistem çerçevesinde yap1lırdı. Öncelikle nabıza dokunulur. "Ĕger nabız şiddetli atarsa kan'ın baskın olduğu ĕ̆er yavaş atarsa safranın baskm olduğu, eğer aralıklarla atarsa balgamın baskın olduğu eğer ince ve geç atarsa sevdanın baskın olduğu anlaşılır." Bu yöntemlerin sonuçları dahilinde hastalığa teşhis koyulurdu (Keykâvus, 1974: 243).

Selçuklu toplumunda tıbbi tedavi yöntemlerinin yanı sıra el temaS1, dua ve telkin gibi manevi metotlar da görülmekteydi. Bu uygulamayı gerçekleştiren hekimlerin başında Selçuklu döneminin alimlerinden olan Mevlânâ Celâleddîn ön planda gelmektedir. Mesela ayak parmakları parçalanmış bir zaatı Mevlânâ bir takım dualar okuyarak sıvazlamış ve yara kapanmıştır. (Eflaki, 1973: 65). O'nun uyku bozukluğu olan bir hastayı telkin ile iyileştirmesi "Birgün kıymetli dostlarından Çelebî Celâleddîn Mevlâna hazretlerine uykusunun fazlalığından şikayet etti. Mevlânâ haşhaşın özünü çıkarıp yemesini tavsiye etti. O da bunu yaptı ama tamamen uykusuz kaldr. Hatta o derece ki, uykusuzluğunun şiddetinden bilinci bozuldu. Bunun için tekrar Mevlânâ'ya müracaat etti. Mevlânâ mübarek elini onun başına sürdü ve o, bu hastalıktan kurtuldu" gibi örnekler mevcuttur. (Eflaki, 1973: 334).

Selçuklu toplumunda görülen yaygın hastalıklardan birisi de akıl hastalıklarıdır. Selçuklular, akıl hastalıklarının tedavisine büyük ehemmiyet vermişlerdir. Bu hususta özel tedavi merkezleri ve tedaviler geliştirmişlerdir. Selçukluların akıl hastalıklarının tedavisinde faydalandıkları yöntemlerin başında "Müzikle tedavi, telkinle tedavi, sicak su, gibi fiziksel tedavileri, cerrahi müdahaleler ve bitkisel ilaç tertipleri" gelmektedir.(Bakır ve Başağaoğlu, 2008: 534) Bu tedaviler, genellikle dârüşşifâ adını verdikleri hastanelerin bir bölümünde uygulanırdı. Bu şifâhânelerde akıl hastalarının tedavisi 
için ayrı bir bölüm tesis edilmiş. Kaynaklara göre bu bölümlerde hastalıkların çeşidine hastalara göre ayrı ayrı müzik terapisi uygulanırd1. (Karahan, 2005: 47; Çoban, 2005: 47).

Selçuklular, akıl hastalarının tedavilerini yaptıkları şifâhânelerin konforuna da önem vermişlerdir. Mesela Gevher Nesibe Şifâhânesi'nde akıl hastaları için tasarlanan oda, dışarıya kapalı ve dışarıdan gelebilecek soğuk veya sıcak hava tehlikelerine karşı tasarlanmış. Şifâhânenin çok sayıda penceresi bulunmayan bir yapıda inşa edilmiş olup, avlu denilen genişce bölgeden ışık ve havanın girmesi sağlanmıştır. Bununla beraber şifâhânenin içerisine hastalara huzur ve dinginlik vereceği düşünülen havuz da yerleştirilmiştir. Hastaların rahatça dolaşabileceği bir avlu, yă̆mur sularının toplandığı su sesinin verdiği huzurun sayesinde ruhi olarak hastalara şifa veren bir mimari tasarımının verdiği huzur, hastaların iyileşmesinde önemli bir etkiye sahipti (Bakır ve Başağaoğlu, 2008: 532). Bu tarz uygulamalar İslami dönem hekimlerinin de uyguladığ1 yöntemler arasında zikredilebilir. Bu açıdan gerek akıl hastaları gerekse muhtelif hastalıklarda müzik tedavisine mahsus çalışmaları bulunan Ebû Bekir er-Râzî, Fârâbî ve İbn Sînâ gibi hekimlerin çalışmaları Selçuklu hekimlerinin kullandığı başlıca kaynaklar olmuştur (Çoban, 2005: 44).

Fârâbî, hastalıklar için çeşitli makamlar geliştirmiş ve makamların hangi vakitlerde dinlenmesi gerektiğini düşünmüştür. Bu makamları rehavî, hüseynî, rast, bûselik, zîrgüle, uşşak, hîcaz, ırâk, nevâ, büzürk makamları olarak sıralayabiliriz. Fecirden önce dinlenen rehavî makamı, insana sonsuzluk fikri vermektedir. Tan yeri ağırmasında dinlenen hüseyni makamı, insana barış, sakinlik ve rahatlık hissi vermektedir. Güneş iki mızrak boyu yükseldiği zaman dinlenen râst makamı, insana neşe ve huzur hissettirmektedir. Kuşluk vakti dinlenen bûselik makamı, güç, kuvvet vermektedir. Öğle vakti zîrgüle makamı dinlenirse uyku hali vermektedir. Öğleden sonra dinlenen uşşak makamı gülme duygusu uyandırmaktayd1 (Üngör, 2002: 230).

İbn Sînâ'ya göre müziğin insanın ruh halini dengelediğini ve insanın ruhunda uyandırdığı telkinlerin motive gücündeki etkisine dikkat çekmektedir (Çoban, 2005: 47). Müzik ile tedavi yöntemleri 
toplumu o kadar etkilemiş ki Osmanlıya kadar etkisini sürdürmüştür. Selçuklularda ruh hastalıkları dışında göz rahatsızlıkları, uykusuzluk, kalp rahatsızlıkları, idrar kaçırma, yüksek ateş gibi hastalıklarda döneminde yaygın görülen rahatsızlıklar arasında zikredilir (Şahsuvaroğlu, 1970: 182).

\section{Bizans Devletinde Hastalık ve Tedavi Yöntemleri}

Bizans dönemininde hekimler hastalığın teşhisi için öncelikle kan aldırmak, perhiz, istirahat, idrar muayenesi, vücudu sıcak tutmak gibi yöntemler uygulanırdı. Bizans devletinde veba, cüzzam gibi salgın hastalıkların yanı sıra Romatizma, akıl hastalıkları, göz hastalıklarının mevcudiyeti söz konusudur. Bizans azizleri ve hekimlerinin, hastalıkları tanrı tarafından insanlara verilen ödül olarak görmesi hastalıklara kutsallık atfedilmesine sebebiyet vermiştir. Mesela epilepsi kutsal saydıkları hastalık türlerinden birisiydi (Demirhan, 2014: 50). Bizans döneminde yayılmış salgın hastalıkların başında ortaçağın yaygın kutsal hastalığı veba gelmektedir. Veba Bizans imparatorluğu sınırları içerisinde baş gösteren salgın hastalık türlerindendir. Veba hastalığı Bizans'a gelmeden önce de çok eskiden birçok bölgede sirayet eden hastalık türlerindendi. Bu manda kutsal kitaplarda vebanın insanlara tanrı tarafından bir ceza olarak gönderildiğine dair bir inanç söz konusudur (Hardman, 2012: 55; Akyay, 1974: 209). Buna sebep olan etken kutsal kitaplarda özellikle Eski Ahid de İsrailoğullarının isyankar davranışlarından dolayı "size veba gönderirim" diye tabir edilen cezalandırma ifadesi tanrının insanlara verdiği çok büyük bir afet olduğunu düşündürmesidir (Varlık, 2011: 175). Feda Şamil Arık'ın bu hastalığın yayılmasını: "Veba Hastalı̆̆ının batıda "plague, black death (kara ölüm), peste, pestis" Anadoluda "kıran, taûn" adıyla bilindiğinden bahsettikten sonra bu hastalı̆̆n esas itibariyle kemiricilerin bir hastalığ. olup "yersinia (pasteurella) pestis" etkeninden (basilinden) ileri gelen veba, insanlara fare pireleri aracılı̆̆ ile bulaşır. Veba mikrobu, hareketsiz, güneşte kolayca ölen, balgam ve pire dışkısı içinde, oda sicaklığında uzun süre canlı kalabilen, dondurulursa 25 yıl canlılı̆̆ın koruyabilen bir basildir. Hastalık genellikle kemirici hayvanlar, fareler arasinda epidemiler şeklinde görülür. "Ksenopsilla Keopis" denilen fare pireleriyle de insanlara geçer. Pire ısırdığı insana, fazla kan emmek için kusmak 
suretiyle infeksiyonu bulaştırır. Pireler bakterileri, ayrıca dışkılarıyla da çıkarabilirler. Kaşınma esnasında açılan kapılardan bakteri insan kanına girer insanlar arasında hastahı̆̆ı bulaşması ancak akciğer vebası şeklinde damlacık infeksiyonu yoluyla olur. Hastah̆̆gn diğer formları kapah infeksiyonlardır, yani pire yoksa insandan insana bulaşma olmaz. Dolayısıyla veba ağırlı̆̆ına ve vücuda yayılmasına göre de türlerine ayrldiğını görüyoruz bunlar; Hıyarcık (bubon) vebası, Akciğer vebası (Veba pnömonisi), veba sepsisi" şeklinde tanımlamaktadır (Arık, 1991: 28).

Bizans Devleti'nde veba salgınının Justinianus zamanında M.S. 541-543 senesinde yayılma gösterdiği bilinir. Bu salgın o dönemde büyük bir nüfus kaybına neden olduğu kaynaklar tarafından zikredilen önemli hususlar arasındadır (Mcevedey, 2004: 36). Prokopius, Bizans'ın Gizli Tarihi, adlı eserinde, veba salgını vehameti hususunda önemli bilgiler vermiştir. Ona göre; dünyada bu salgını hissetmeyen ve bu salgından kurtulabilen tek bir kişi bile bulunmamaktadır. (Prokopius, 2001: 59). Veba salgını o kadar güçlü hissedilmiş ki imparator Justinianus'un da etkilenmesine sebebiyet vermişti. Justinianus, hastalığı süresince yönetimi eşi Theodora'nın bir süre sürdürdüğüne ilişkin rivayetler söz konusuydu (Bakır ve Ülgen, 2017: 30). Vebanın yayılmasında İmparator Justinianus'un bir nevi etkili olduğunu söyleyebiliriz. Çünkü veba salgınının fareler, evcil kediler, sincap ve pireler gibi kemirici hayvanlardan insanlara bulaşan bir tür salgın hastalıktır (Hardman, 2012: 56). Bu manada Bakır ve Ülgen'in (2017: 30) tespitine göre; Justinianus'ın iktidarını genişletmek için verdiği mücadelelerin bir türlü son bulmaması ve bunun için en zirve başarıya ulaşmasını Afrika'da bulunan buğday, pamuk, ipek, keten ve diğer değerli eşyaların ithali sağlayacaktır. Bizans bünyesine bu varlıkların taşınması esnasında farelerin ve onlarla beraber gelen pirelerin ve pek çok mikrobun yayılmasını kolaylaştırıyordu. Dolayısıyla imparator Justinianus'un iktidarlık hırsı, hastalığın imparatorluk üzerinde yayılmasını kolaylaştırmıştır.

Bizans devleti veba salgınlarına karşı birçok tedbir almaya çalışmıştır. Fakat dönemin doktorları bu hastalık hususunda pek de kalıcı tedaviler keşfedememişlerdi. Çünkü Bizans doktorları birçok vebalı hastayı hastalığın hızlı bir şekilde yayılmasından ha- 
bersiz tedavi etmeleri neticesinde pek çok insanın katline sebebiyet verdikleri kaynaklar tarafindan nakledilir. Doktorların bu hususta yaptıkları işlemler bitkisel ve kimyasal ilacı insan vücudunda uygulayıp hastalığın içindeki irinin dışarı çıkmasını sağlamaktan başka bir şey değildi. Bu yaptıkları işlem de hastalığın vücutta daha da yayılmasına zemin hazırlamaktaydı. Bu nedenle bir çok doktorun hastalık hususunda çaresiz kaldığı nakledilir (Bakır ve Ülgen, 2017: 31). Neticede vebanın tedavisi hususunda Bizans hekimlerinin çalışmaları da yetersizdi.

Bizans devletinde veba kadar etkili olan hastalıklardan bir diğeri de cüzzam hastalığıdır. Bu hastalığın ne şekilde yayıldığı, ne gibi uygulamalar yaptıklarına ilişkin elimizde herhangi bir veri bulunmamaktadır. Bizans devletinde normal görülen hastalıklar dışında zehirlenmelerde olmaktaydı. Bu tür zehirlenme hastalıklarının tedavisinde iyi olduğu sanılan tedavilerin başında çeşitli isimler verdikleri topraklar gelir. Bu topraklardan birisi "Terra Lemnia" (Kırmızı Toprak) adını verdikleri zehirlenmeleri önceden haber veren bir yapıya sahip olan, ülser ve dizanteriye de iyi geldiği bilinen topraktır. Kırmızı toprak, Aziz Simeon Stylites'in yerleştiği yerde bulunur. Bu toz oradan alınarak ondan özel mühürlü kaplar yapılır ve değişik sıvılar ile karıştırılıp kutsanırdı. Bu tozun hastalara şifa vereceği düşünülürdü. Burada kutsayıcı unsur aslında azizlerin manevi yüceliği ve duvarlarından elde ettikleri tozdur. Zehirlenmelerde bir diğer tedavi edici madde ise sirkedir. Mesela zehirli bir yılan soktuğunda sirkenin yara üzerine uygulanmasıyla tedavi gerçekleşirdi (Pralong, 2016: 250-251).

Bizans'ın, yaygın bu hastalıkları dışında bilinen, salgın olamayan hastalıklar da mevcuttur. Bu hastalıklara, göz, romatizma, akıl, fitık, gut ve epilepsi gibi örneklendirilebilir (Demirhan, 2014:29). Bizans hekimlerinin hastalıkların teşhisinde ugulanan ilk yöntem nabız ve idrar muayenesidir. İleri derece bir rahatsızlık söz konusu ise cerrahi müdahalelere de başvurulurdu. (Vallianatos, 2015: 105). Bizanslı hekimler nabız ve idrar muayenesinin ardından hastanın durumuna göre ilaç tedavisi uygulamaktadırlar. Hekimler, hastalara genellikle bitki karışımları ile elde ettikleri "Tiryak" adını verdikleri ilaç tedavisi uygulardı. Bu karışım, altmış dört 
çeşit malzemenin harmanlanmasıyla hazırlanırdı. Tiryakların hazırlanması için özel bir merasim düzenlenirdi. Bu ilacın içindeki maddeler "zencefil, ravend, karabiber, giritotu, maydanoz tohumu, afyon, kurutulmuş ekmek içi, günlük, zift, çavşır, mürsafi, kurutulmuş yılan kalbi" gibi bitkilerden oluşuyordu (Baylav, 1968: 50). Bir diğer tiryak da M.Ö I. yüzyılda Pontus Kralı Mitrat tarafından keşfedildiği sanılan Mitridatyum adı ile de bilinen karışımdır. Bu tiryak bir çok hastalığın tedavisinde panzehir olarak kullanılmıştır. İçerisinde; engerek otu, afyon, adasoğanı karışımından elde edilen bir ilaç mevcuttur. Tiryak dışında; Antidotum Orvietanum, Antidotum Orvietanum Aliud, Antidotus Matthioli, Antidotus Matthioli reformatus gibi panzehirler de kullanılmıştır (Baylav, 1968: 69). Bizans hekimleri tıbbi tedavilerinde bitki ve baharat tarzı ilaç kullanımını yaygın olarak tercih ederlerdi. Bu bitkileri döneminde yaygın olarak kullandıkları ilaç reçetelerinden incelemek kuvvetle muhtemeldir. Reçetelerde genellikle bahsedilen bitkiler sarısabır, akgünlük, mür ve biber gibi ürünlerdir. Bu ilaçlar Asya kökenli olup yakın doğu ve Güney Asya'dan ithal edilmekteydi. (Durak, 2015: 153). Bizans'ta eczacilık sistemini de bulunmaktayd. Bitkisel ilaçları satan veya çeşitli yerlerden toplayan, bu bitkilerden ilaç veya başka yollarda kullanan kişiler de mevcuttu. Kokulu maddeler satan Aromatarius, çeşitli otsu bitkileri toplayıp satan kişi Herbarius, ilaç hazırlayan eczacı Pharmakopoeos, ilacı satan kişi Pharmakopolos, ilaçları seyyar olarak satan Pharamakopolae circumforaneae, bitki özleri, kremler ve çeşitli kozmetik ürünleri hazırlayan Pigmentarius gibi kişiler bunlardan bazılarıdır (Baytop, 2000: 27). Tıbbi reçetelerden pek çok bilgiye vakıf olunabilir. Mesela kan alma, cerrahi müdahaleler, çeşitli tıbbi ilaçlar ve talimatlar yapıldığına ilişkin bilgiler bu reçetelerin içerisinde yer alırdi.

Bizans döneminde bir tedavi yöntemleri olarak bilinen çeşitli büyüler, efsunlar ve kutsal kitaplardan elde edilen şifâ-i unsurlar da bulunmaktaydı. Bu tarz yöntemin şifa vereceğine inanan Gallen, Aginalı Paulus ve Oribasios gibi Bizans hekimlerinin büyüsel reçeteleri hastalarına uyguladıkları kaynaklar tarafından zikredilir (Vallianatos, 2015: 109). Hekimlerin büyülere ve çeşitli sihirsel un- 
surlara inanmalarındaki amaç vuku bulan hastalıklara şeytanların musallat olmasıydı. Bu nedenle çeşitli büyüsel simgelere ve muskalara ihtiyaç duymuşlardı. Bu simgeler arasında haç, tılsım, çanlar, kırmızı iplikler gibi unsurlar sayılır. Hac şeytani kötülüklerin ortadan kalkmasına vesile olan en büyük simgelerden birisidir. Sadece kötü ruhları atmak için değil iyi şans getirmesi sevgi, muhabbet bağını arttırmak için de bu simgeler üzerinden muskalara ve büyülere başvurulurdu (Köroğlu, 2005b: 159). Bunun dışında kutsal saydıkları taslar ile tedavileri de söz konusudur. Bu taslar ile hamamda yıkanılırdı. O'nun kadınlarda kolay bir doğum sağladığ1 veya düşüğü engelleyici, ağrı kesici etkiye sahip olduğuna inanılmaktaydı (Köroğlu, 2005b: 162).

\section{Selçuklu ve Bizans Devletlerinin Tedavisinde Ayrışan Noktalar}

Tibbi tedavi hususunda Bizans ve Selçuklu Devletleri'nin benzer yönlerinin olduğu gibi ayrışan noktaları da vardır. Selçuklu devletinde Müzikle tedavi sistemini ilk ayrışan noktalar arasında zikredilir. Müzik, devletler için çeşitli toplumsal değerlerin bir simgesiydi. Özellikle Selçuklularda, resmi törenlerde, savaş, orduda eğlence, çocukları uyutma, sultanların kapılarında nevbet gibi zamanlarda kullanılıyordu (Kaya, 2011: 160-161). Selçuklu devletleri, müziği psikolojik çerçevede insanların akıl hastalığı tedavisinde de kullanmışlardı. Bu hastalar, derecelerine göre ayrı odalara yerleştirilirdi.

Her hastalığın cinsine göre özel müzik besteleri tedavi için uygulanırd1. Kaynaklardan öğrendiğimize göre bu yöntemle pek çok hastanın, hastalığının tedavisine müzükle etki etmeye çalışılmış (Altınölçek, 2002: 1412). Müzik Bizans kültürel unsurlarında müziği sadece kilise musikisi şeklinde kullanılmıştır (Mimaroğlu, 1961: 19).

Bizans ve Selçuklu Devletleri'nin tedavi hususunda ayrıştıkları bir diğer nokta ise; Bizans hekimlerinin tedavilerinde büyü, sihir unsurlarına ve doğaüstü yöntemlere fazlaca yer vermesi söz konusu iken Selçuklu hekimlerinin daha çok ilmi açıdan bilimsel yöntemleri ön plandaydı. (Lyons ve Petrucelli 2008: 265). Bizans hekimleri büyüsel, sihirsel tedavilerinde hastalanan kişinin içe- 
risine şeytan girdiğini düşünerek onu çıarmak için akıl almaz yöntemler denerdi. Şeytanın hasta insanların içine girdiği ve onu çıkarmak için de bir şeytan çıkarıcının getirtildiği bu kişinin hastanın göğsüne kuvvetlice vurmak suretiyle onu çıkardığ1 rivayet edilir. Eğer şeytan çıkmazsa hastanın kasıldığı, kıyafetlerini parçaladığı ve bilincini kaybedeceği için hekimler böyle bir yöntememi uygun görmekteydi. (Mongo, 2008: 180). Bu durumun dışında hastalıklardan korunmak için çeşitli tılsımlar, nazarlık ve büyülü nesneler taşıyarak korunabilecekleri inancı hakimdi. (Eco, 2014: 486). Selçuklu döneminde bu tür uygulamalara pek rastlanmaz. Fakat dönemin alimlerinden olan Mevlânâ'nın herkesin elinde bulunan bitkisel, hayvansal ve telkin tedavileri çerçevesinde daha çok halk hekimliğine dayalı bir tedavi şekli uygulamaktaydı. Aynı zamanda hastaların iyileşmesi hususunda ilaçla tedaviyi de teşvik etmiş. Rivayete göre Sultan Veled'e hastalıkları iyileştirmek için ilaçlar, macunlar getirdiğini, her ilacın özelliklerinin farklı olduğunu belirterek ilaçları tavsiye etmiş. Doktorların bu özelliklere göre o ilaçlara talip olduğu nakledilir. (Merçil, 2000: 117). Ateşli bir hastalığa sarımsak taneleri yedirerek sağlığına kavuşturması, Sinüzit hastalarına kına tedavisi uyguladığı ve cüzzamlı hastalar için de hamama gitmelerini önerdiğini dönemin kaynakları çerçevesinde inceleyebiliyoruz (Eflaki, 1973: 293). Bizanslılar ise hastalığın tanrı tarafından verilen bir ceza veya mukâfat olarak değerlendirmekteydi. Bu nedenle şifayı verecek olanın da yalnızca tanrının merhameti ile olacağına inanılırdı. (Lyons ve Petrucelli, 2008: 272). Bu yüzden Bizans toplumu hastalık geldiğinde acı çekerek vefat etmeyi uygun görmüş.

Selçuk ve Bizans Devletleri'nin ilaç tedavisi yöntemleri ve eczac1lık sistemindeki yansımaları hemen hemen aynıydı. Bizanslı hekimlerin çeşitli tercümeleri Müslüman Selçuklulardan elde etmek sureti ile ilaç yapımı hususundaki bilgileri kendilerine aktarmışlardı. Bu hususta Bizanslı hekim Simeon Seth, Arapça tercümeleri ile bilinir. Seth, İlaç hususunda çok sayıda veriyi Bizansa aktararak ilaç biliminin gelişiminde söz sahibi olmuştur. (Memmedova, 2010: 597). Bizanslılar ilaç yapımında kullandıkları bitkileri manastır bahçesinde özel olarak yetiştirirken, Selçuklular Hindistan 
ve Anadolu' nun çeşitli bölgelerinden temin ettiklerini kullanırdı. Özel olarak ilaç yapımında kullanılan bu bitkiler ya ithal edilen ya da bölgede bulunan yerlerden Selçukluya getirilir ve belirli pazar yerlerinde satılırdı. Bu yerler genellikle aktar (çeşitli bitkiler satan dükkan) olarak da kullanılan yerlerdi. Aktarlardan ilaç yapımında uygun olan bitkiyi seçen hekimler pek çok macunun hazırlanmasında bilgi sahibiydi. (Turan, 2014: 52). Bu bağlamda yetiştirmiş oldukları "üzüm, ayva, nar, çoban yastığı, susam, badem, maydanoz, dereotu, soğan, sarımsak" gibi karışımlardan elde ettikleri macunları tedavide uygulanırdı (Memmedova, 2010: 597). Selçuklular ise tiryak olarak nitelendirdikleri karışımlar elde ederlerdi. Bununla çeşitli yara ve cerrahi işlemlerin ağrısını önlerlerdi. Özellikle bu hususta Ekmeleddîn al-Nahcivânî́yi usta isimler arasında zikredilir. (Merçil, 2011:117).

\section{Sonuç}

Selçuklu ve Bizans toplumunda baş gösteren hastalıkların hemen hemen aynı olduğu görülmektedir. Özellikle direndikleri hastalıkların başında veba salgınlarının geldiği ve her iki devletin de bu hastalık karşısında çaresiz kalmışlardır. Tedavi yöntem ve uygulamalardaki hassasiyetleri her iki devlet için de önem arz etmekle beraber farklılıklar göstermektedir. Bu manada Selçuklu tıbbında uygulanan yöntem ve esaslar daha çok bitkisel, kimyasal ilaç boyutunda iken, Bizans tıbbında uygulanan tedavilerin bitkisel olmakla beraber büyüsel unsurların daha çok ön planda oldu$\breve{g} u$ hissedilir. Ayrıca hastalıkların tanrı tarafından bir ödül olarak verildiği inancl, Bizans hekimlerini tedavi anlamında engelleyen en büyük etken olmuştur. Selçuklu hekimleri ise baş gösteren hastalıklar hususunda elinden gelen yöntem ve uygulamaları denemekten çekinmemişlerdir. 
Seyhan Atak

\section{Kaynakça}

ABÛL-FARAC, G. (1987), Ab̂̂'l-Farac Tarihi, II, Çev. Ömer Rıza Doğrul, Ankara: Türk Tarih Kurumu Yayınları.

AKYAY, N. (1974), “Türkiye' de Veba Salgınları ve Veba Hakkında Eski Yayınlar", 8(2), Mikrobiyoloji Bülteni, Ankara: Bilimsel Tip Yayınları, s.209-219.

ALTINÖLÇEK, H. (2002), “Türk Tıbbında Müzikle Tedavi”, Türkler Ansiklopedisi, Cilt 5, Ankara: Yeni Türkiye Yayınları, s.14121423.

ARIK, F.Ş. (1991), "Selçuklular Zamanında Anadolu'da Veba Salginları" 15(26), Tarih Araştırmaları Dergisi, Ankara: Ankara Üniversitesi Yayınları, s.27-57.

BAKIR, B. ve Başağaoğlu, İ. (2008), “Akıl Hastalıklarında Geleneksel Tedaviler ve Birkaç Selçuklu Darüşşifa Yapısı Tasarımı Üzerindeki Etkileri", I. Uluslararası Türk Tıp Tarihi Kongresi 10. Ulusal Türk Tıp Tarihi Kongresi Bildiri Kitabı, Cilt 1, (Yay. Haz.). Ayşegül Demirhan Erdemir, Öztan Öncel, Yusuf Küçükdağ, Berrin Okka, Sezer Erer, İstanbul: Türk Tarih Kurumu Yayınları, s.530-644.

BAKIR, A. ve ÜLGEN, P. (2017), “Bizans'ta Tababet Kültürü Bilimi ve Çalışmları Üzerine Genel Bir Değerlendirme”, Cappadocia Journal of History and Soctal Sciences, Vols.1-9, Nevşehir: Nevşehir Hacı Bektaş Üniversitesi Yayınları, s.15-39.

BAYLAV, N. (1968), Eczacılık Tarihi, İstanbul: Yörük Yayınları.

BAYTOP, T. (1985), Türk Eczacılık Tarihi, İstanbul: İstanbul Üniversitesi Yayınları.

ÇOBAN, A. (2005), Müzikterapi Ruh Sağhlğı İçin Müzikle Tedavi, İstanbul: Timaş Yayınları.

DEMIRHAN, A. (1994), Tip Tarihi ve Deontoloji Dersleri, Bursa: Uludağ Üniversitesi Yayınları.

DENIZKUŞLARI, M. (2018), Kur'an-ı Kerim ve Hadislerde Tıp, Konya: Hüner Yayınları.

DURAK, K. (2015), “Dioskorides ve Ortaçağ, Bizans İmparatorluğu'na İthal Edilen Tibbi Bitkiler", Hayat Kısa, 
Sanat Uzun Bizans'ta Şifa Sanatı, Pera: Pera Müzesi Yayınları, s.153-160.

ECO, U. (2014), Ortaçağ (Barbarlar, Hristiyanlar, Müslümanlar), Çev. Leyla Tonguç Basmacı, İstanbul: Alfa Basım Yayınları.

EFLAKİ, A. (1973), Ariflerin Menkıbeleri (Menakib al-Ârifin), Cilt 1, Çev. Tahsin Yazıcı, İstanbul: Hürriyet Yayınları.

EL-ÖMERİ, Ş. (2014), Şihabeddin b. Fazlullah, Mesâliku'l Ebsâr (Türkler Hakkında Gördüklerim ve Duyduklarım), Çev. D.Ahsen Batur, İstanbul: Selenge Yayınları.

ERSOY, T. (1994), Tip Tarih Metafor, Ankara: Öteki Yayınları.

HARDMAN, L. (2012), The History of Medicine, Amerika: Lucent Books Perss.

İBN KESİR (2017), El Bidaye Ve'n Nihaye, İslam Tarihi, Cilt 1, Çev. Mehmet Keskin, İstanbul: Çağrı Yayınları.

KAHRAMAN, A. (2011), “Tedavi”, Türkiye Diyanet İslam Ansiklopedisi Cilt 40, İstanbul: Türkiye Diyanet Vakfı Yayınları, s.254-256.

KAHYA, E. (2003), “Anadolu Selçuklularının Bilimsel Faaliyetlerinin Genel Bir Değerlendirmesi", III. Uluslararası Mevlana Kongresi Bildiriler, Konya: Selçuk Üniversitesi Matbaası Yayınlar1, s.245-252.

KARAHAN, S. (2006), “Tarihsel Süreç İçerisinde Türklerde Müzikle Terapi", Basılmamış Yüksek Lisans Tezi, İstanbul: İstanbul Üniversitesi Sosyal Bilimler Enstitüsü Müzik Anasanat Dall.

KAY, E. (2008), “Muyîddin Mehî’nîn Mûfid (Nazmü't-Teshil) Adlı Eseri (İnceleme-Metin Dizin) ve Bu Eserin XV. Yüzyıl Türk Tıp Dili'nin Oluşumundaki Yeri" (Yayımlanmamış Doktora Tezi), Konya: Selçuk Üniversitesi Sosyal Bilimler Enstütüsü Türk Dili ve Edebiyatı Ana Bilim Dalı Türk Dili Bilim Dalı.

KAYA, A. (2004), “İslam Hukukuna Göre Hekimin Tıbbî Müdaheleden Doğan Hukukî ve Cezaî Sorumluluğu”, İslâmî Araştırmalar Dergisi, 17(4), Ankara: TEK-DAV Yayınları, s.295-307.

KAYA, E. E. (2011), “Anadolu Selçuklu Medeniyetinde Türk Mü- 
zik Kültürü", II. Uluslararası Selçuklu Kültür ve Medeniyeti Bilim ve Düşünce Sempozyumu Bildirileri Kitabı, Konya: TTK Yayinlarl, s.160-161.

KESGİN, S. (2014), “(Hastalıkta) Bulaşıcılık Yoktur" Hadisinin İsnad ve Metin Açısından Tahlili, 13(26), Hitit Üniversitesi Fakültesi Dergisi, Çorum: Hitit Ünüversitesi Yayınları, s.83-120.

KEYKÂVUS, (1974), Kabu'sname, Çev. Mercimek Ahmet, Haz. Orhan Şaik Gökyay, İstanbul: Milli Eğitim Bakanlığı Yayınları.

KÖROĞLU, G. (2005a), “Bizans'ta Hekim Azizler, Eyüp'teki Kosmos ve Domianos Kilisesi", Eyüp Sultan Sempozyumu Tebliğler I-VIII, İstanbul: Eyüp Belediyesi Kültür Yayınları, s.240-246.

KÖROĞLU, G. (2005b) “Bizans Döneminde Nazar ve Kadın Hastalıklarına Karşı Kullanılmış Muskalar" , Cilt 1, 38. Uluslararası Tip Tarihi Kongresi Bildiri Kitabı, Ed., Nil Sarı, Ali Haydar Bayat, Yeşim Ülman, Mary Işın, Ankara: Türk Tarih Kurumu Yayınları, s.159-166.

LYONS, A. S. ve Joseph R. P. (2008), Çağlar Boyu Tıp, Trc. Nilgün Güdücü, Bostan: Omaş Yayınları.

MANGO, C. (2008), Bizans Yeni Roma İmparatorluğu, Çev.Gül Çağalı Güven, İstanbul: Yapı Kredi Yayınları.

MATEOS, U. (1962), Vekayi-nâmesi (952-1136) ve Papaz Grigor'un Zeyli (1136-1162), Çev. Hrant D. Andreas, Ankara: Türk Tarih Kurumu Yayınları, s.177-178.

MCEVEDY, C. (2004), Ortaçağ Tarih Atlası, Çev. Ayşen Anadol, İstanbul: Sabancı Üniversitesi Yayınları.

MEMMEDOVA, N. (2010), “Bizans'ta Sağlık-Temizlik ve Hastane İşi”, Geçmişten Günümüze İstanbul'da Sağlık Kongre Bildiri Kitabı, İstanbul: Nobel Yayın Dağıtım, s.593-598.

MERÇİL, E. (2000), Türkiye Selçuklularında Meslekler, Ankara: Türk Tarih Kurumu Yayınları.

MIMAROĞLU, İ. K. (1961), Musiki Tarihi, Ankara: Varlık Yayınları.

PRALONG, A. (2016), Bizans Yapılar, Meydanlar, Yaşamlar, Çev. Buket Kitapçı Bayrı, İstanbul: Kitapyayınevi. 
PROKOPIUS, (2001), Bizans'ın Gizli Tarihi, Çev. Orhan Duru, İstanbul: Türkiye İş Bankası Kültür Yayınları.

SEMERKANDİ, N. A. (2016), Çehâr Makale, Çev. Esin Eren Soysal, İstanbul: Demavend Yayınları.

ŞAHSUVAROĞLU, B. (1970), Eczaculık Tarihi Dersleri, İstanbul: İstanbul Üniversitesi Yayınları.

TANERİ, A. (1978), Türkiye Selçukluları Kültür Hayatı, Konya: Bilge Yayınları.

TEKINER, H. (2006), Ortaçağ Tıp Tarihinde Öncü Bir Kurum Gevher Nesibe Dârüşşifası, Kayseri: Türk Eczacılar Birliği Yayınları.

TEKINNER, H. (2014), “Gevher Nesibe Darüşşifası ve Selçuklularda Tıp", I. Uluslararası Selçuklu Sempozyumu Selçuklu Tarihi Bilim ve Düşünce, Ankara: Türk Tarih Kurumu Yayınları, s.179-368.

TURAN, O. (2014), Türkiye Selçukluları Hakkında Resmi Vesikalar, Ankara: Türk Tarih Kurumu Yayınları.

ÜNGÖR, E. R. (2002), “Ortaçağdan İki Musiki Öncümüz; İlk Bilinen Halk Ozanımız Dede Korkut ve En eski Musiki Âlimimiz Türkistanlı Türk Fârâbi", Türkler Ansiklopedisi, Cilt 6, Ankara: Yeni Türkiye Yayınları, s.218-257.

ÜNVER, S. (1938), Tip Tarihi, Ankara: İstanbul Üniversitesi Yayınlari.

ÜNVER, S. (2014), XI-XIV. Asırlar Selçuk Tababeti Büyük Selçuklu Imparatorluğu ve Orta Zamanda Anadolu Türk Devletleri Tababeti Tarihine Dair, Ankara: Türk Tarih Kurumu Yayınları.

VALLİANATOS, P. B. (2015), “Bizanslı Hekimlerin Şifa Sanatı Bağlamının İncelenmesi", Hayat Kısa, Sanat Uzun Bizans'ta Şifa Sanatı, Çev. Ayşe Düzkan, Melis Şeyhun Çalışlar, Orçun Türkay, Pera: Müzesi Yayınları, 2015, s.105-122.

VARLIK, N. (2011), "Tâun", Türkiye Diyanet İslam Ansiklopedisi, Cilt 40, İstanbul: Türkiye Diyanet Vakfı Yayınları, s. 175-177. 